The True Identity of the Fungus Reported as Hirsutella gigantea from Eastern Spruce Budworm in Canada

Author(s): D. B. Strongman and E. S. Eveleigh

Source: Mycologia, Vol. 84, No. 6 (Nov. - Dec., 1992), pp. 937-939

Published by: Mycological Society of America

Stable URL: http://www.jstor.org/stable/3760297

Accessed: $17-06-2015$ 12:20 UTC

Your use of the JSTOR archive indicates your acceptance of the Terms \& Conditions of Use, available at http://www.jstor.org/page/ info/about/policies/terms.jsp

JSTOR is a not-for-profit service that helps scholars, researchers, and students discover, use, and build upon a wide range of content in a trusted digital archive. We use information technology and tools to increase productivity and facilitate new forms of scholarship. For more information about JSTOR, please contact support@jstor.org. 
Mycologia, 84(6), 1992, pp. 937-939.

(C) 1992, by The New York Botanical Garden, Bronx, NY 10458-5126

\title{
THE TRUE IDENTITY OF THE FUNGUS REPORTED AS HIRSUTELLA GIGANTEA FROM EASTERN SPRUCE BUDWORM IN CANADA
}

\author{
D. B. Strongman \\ Biology Department, Saint Mary's University, Halifax, Nova Scotia B3H 3C3, Canada
}

AND

E. S. Eveleigh

Forestry Canada-Maritimes Region, P.O. Box 4000, Fredericton, New Brunswick E3B 5P7, Canada

In 1949, D. M. MacLeod at the Forest Insect Laboratory, Sault Ste. Marie, Ontario, sent specimens of a fungal entomopathogen isolated from eastern spruce budworm (Choristoneura fumiferana (Clem.)) collected in Ontario to E. B. Mains, University of Michigan for identification. Mains tentatively identified the pathogen as $\mathrm{Hir}$ sutella gigantea Petch; we assume that it was a tentative identification because he wrote "may be this species" (Mains, 1951). Following Mains, MacLeod (1959) and Loughheed (1963) in Ontario, and Lim (1984) in Newfoundland all referred to isolates of Hirsutella from spruce budworm as $H$. gigantea.

Meanwhile, over the past decade, we have examined more than 10,000 spruce budworm specimens collected from seven sites in New Brunswick, Canada. Some of these specimens yielded two Hirsutella species not previously reported from spruce budworm. We identified one as Hirsutella nodulosa Petch and the other as a new species Hirsutella longicolla Strongman, Eve- leigh \& Royama with a variety $H$. longicolla var. cornuta Strongman, Eveleigh \& Royama (Strongman et al., 1990). Curiously, however, we have never recovered $H$. gigantea from our collections in New Brunswick.

The complete absence of $H$. gigantea in our large collections made us wonder whether the fungal isolates previously reported as $H$. gigantea from spruce budworm had in fact been misidentified. To check this possibility, we examined specimens identified as $H$. gigantea from three sources: MacLeod's original specimens from Ontario (ONT) that Mains examined; Lim's specimens from Newfoundland (NFLD); and the type of $H$. gigantea (FH 6126). We compared these with the type of $H$. longicolla (DAOM 196534). TABLE I summarizes the measurements and description of these specimens. We compared the phialide morphology of $H$. gigantea (FH 6126) (FIG. 1) with MacLeod's (ONT) (FIG. 2) specimen and $H$. longicolla (DAOM 196534) (FIG. 3) from New Brunswick.

TABLE I

SUMMARY OF MEASUREMENTS FOR HIRSUTELLA SPECIES

\begin{tabular}{|c|c|c|c|c|}
\hline Trait & $\begin{array}{c}H . \text { longicolla } \\
\text { New Brunswick } \\
\text { Type }\end{array}$ & $\begin{array}{l}\text { 'H. gigantea' } \\
\text { Newfoundland }\end{array}$ & $\begin{array}{c}\text { 'H. gigantea' } \\
\text { MacLeod, } 1949\end{array}$ & $\begin{array}{l}\text { H. gigantea } \\
\text { Petch, } 1937 \\
\text { Type }\end{array}$ \\
\hline \multirow[t]{2}{*}{ Synnema } & Green, simple & Green, simple & Green, simple & $\begin{array}{l}\text { Brown, simple or } \\
\text { branched }\end{array}$ \\
\hline & $0.1-1 \mathrm{~cm}$ & $<1 \mathrm{~cm}$ & $<1 \mathrm{~cm}$ & $2-10 \mathrm{~cm}$ \\
\hline Phialide base & $6-14 \times 6-10 \mu \mathrm{m}$ & $7-10 \times 7-12 \mu \mathrm{m}$ & $7-15 \times 6-8 \mu \mathrm{m}$ & $16-20 \times 8-9 \mu \mathrm{m}$ \\
\hline Phialide neck & $21-36 \mu \mathrm{m}$ & $12-27 \mu \mathrm{m}$ & $15-23 \mu \mathrm{m}$ & $<20 \mu \mathrm{m}$ \\
\hline Spores & $\begin{array}{l}\text { Cymbiform tapered } \\
6.5-10.5 \times 2.5-5 \mu \mathrm{m}\end{array}$ & $\begin{array}{l}\text { Cymbiform obtuse } \\
8 \times 4 \mu \mathrm{m}\end{array}$ & $\begin{array}{l}\text { Cymbiform tapered } \\
8 \times 4 \mu \mathrm{m}\end{array}$ & $\begin{array}{l}\text { Cymbiform obtuse } \\
9-10 \times 3-4 \mu \mathrm{m}\end{array}$ \\
\hline
\end{tabular}



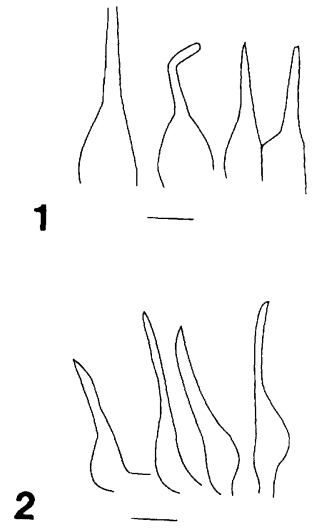

3

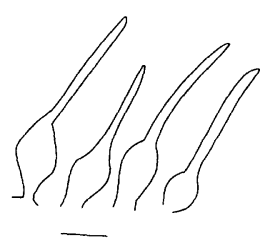

FIGs. 1-3. Phialide morphology of Hirsutella. 1. H. gigantea type specimen (FH 6126). 2. H. gigantea (MacLeod specimen, ONT). 3. H. longicolla type specimen (DAOM 196534). Scale bars $=10 \mu \mathrm{m}$.

The comparisons reveal that the ONT and NFLD specimens are, indeed, more like $H$. longicolla than $H$. gigantea. The critical comparison is the phialide dimensions since this is the main feature for separation of species in this genus (Mains, 1951; Minter and Brady, 1980). The phialide base of $H$. gigantea (FH 6126) is more cylindrical than the globose phialide base in the other specimens (FIGS. 1-3). (H. nodulosa, the other species known from spruce budworm, has warty phialides with a helical, twisted tip (Minter and Brady, 1980) making it very distinct from both $H$. longicolla and $H$. gigantea.) Furthermore, the synnemata of the ONT and NFLD specimens are similar in size to those of $\mathrm{H}$. longicolla (DAOM 196534), but they are much smaller than those of the type of $H$. gigantea (TABLE I).

An interesting observation comes from Loughheed (1963). During his sporulation experiment with an isolate named $H$. gigantea from spruce budworm in Ontario, he noted that the phialide and spore characteristics in vitro matched neither the original description of the species by Petch (1937) nor Mains' (1951) redescription of the type. However, the morphological measurements recorded by Loughheed match those for H. longicolla.

Apart from the questionable records of $\mathrm{H}$. gigantea from the spruce budworm mentioned above, we are aware of a few more records of this fungus, all from northeastern USA. Petch (1937) mentions three records: the type specimen from the American dagger moth (Acronicta (= Apatela) americana (Harris)), one from Acronicta (= Apatela) sp., and one more from an unidentified host. Wagner and Leonard (1980) reported it from the satin moth (Leucoma salicis (L.)). It may be that $H$. gigantea attacks macrolepidoptera, unlike $H$. longicolla which has so far been restricted to microlepidopteran hosts (Strongman et al., 1990).

In conclusion, we are certain that the Hirsutella specimens from Ontario and Newfoundland are actually $H$. longicolla and believe that this species occurs throughout the geographical range of the eastern spruce budworm.

We thank the University of Michigan Herbarium (M) for the loan of the MacLeod (ONT) specimens, the Farlow Herbarium (FH) for the loan of the type of $H$. gigantea, and K. P. Lim, Forestry Canada, St. John's, Newfoundland for the NFLD specimens. We also thank Drs. C. J. Lucarotti and Tom Royama for their critical comments on the manuscript. This work was funded in part by a Natural Science and Engineering Research Council Visiting Fellowship and operating grant to D. B. Strongman.

Key Words: Choristoneura fumiferana, Hirsutella gigantea, Hirsutella longicolla, spruce budworm, taxonomy

\section{LITERATURE CITED}

Lim, K. P. 1984. Biological mortality factors of the spruce budworm in Newfoundland. Pp. 504-505. In: Recent advances in spruce budworm research. Eds., C. J. Saunders, R. W. Stark, E. J. Mullins, and J. Murphy. Supply and Services Canada, Ottawa, Ontario, Canada.

Loughheed, T. C. 1963. Studies on the morphology of synnemata of Hirsutella gigantea Petch. Canad. J. Bot. 43: 947-955.

MacLeod, D. M. 1959. Nutrition studies on the genus Hirsutella 1. Growth response in an enriched liquid medium. Canad. J. Bot. 57: 695-714.

Mains, E. B. 1951. Entomogenous species of Hirsutella, Tilachlidium, and Synnematium. Mycologia 43: 691-718.

Minter, D. W., and B. L. Brady. 1980. Mononematous species of Hirsutella. Trans. Brit. Mycol. Soc. 74: 271-282. 
Petch, T. 1937. Notes on entomogenous fungi. Trans. Brit. Mycol. Soc. 21: 34-67.

Strongman, D. B., E. S. Eveleigh, and T. Royama. 1990. Hirsutella longicolla sp. nov. and $H$. longicolla var. cornuta var. nov.: two new fungi pathogenic to the spruce budworm, Choristoneura fumiferana (Lepidoptera: Tortricidae). J. Invert. Pathol. 55: 11-16.

Wagner, T. L., and D. E. Leonard. 1980. Mortality factors of satin moth, Leucoma salicis [Lep.:Lymantriidae], in aspen forests in Maine. Entomophaga 25: 7-16.

Mycologia, 84(6), 1992, pp. 939-944.

(C) 1992, by The New York Botanical Garden, Bronx, NY 10458-5126

\title{
SCUTELLOSPORA ARMENIACA, A NEW SPECIES IN GLOMALES (ZYGOMYCETES) FROM POLAND
}

\author{
JANUSZ BŁASZKOWSKI \\ Department of Plant Pathology, Academy of Agriculture, \\ Stowackiego 17, PL-71434 Szczecin, Poland
}

Spores of an undescribed species of the genus Scutellospora Walker \& Sanders were found in soils collected from the root zone of plants colonizing maritime dunes of the Hel Peninsula and the Słowiński National Park and of plants growing on the Błędowska Desert (a site situated ca $500 \mathrm{~km}$ from the Baltic Sea). Because of the apricot-yellow color of the spores, the species was named $S$. armeniaca.

Soils were collected from around plant roots and then refrigerated until processing. Spores were extracted by wet sieving and decanting (Gerdemann and Nicolson, 1963). Spores were first propagated in $500 \mathrm{~cm}^{3}$ pot cultures prepared from autoclaved quartz sand to which about $200 \mathrm{~g}$ of a field-collected soil/root mixture containing a large number of spores and mycorrhizal roots was added. The potting medium was then seeded with Festuca rubra L. and Sorghum sudanense (Piper) Staph. After 3-5 months of culture, newly formed spores were used to prepare pure pot cultures. An autoclaved soil : sand mixture (1:3, $\mathrm{v} / \mathrm{v}), \mathrm{pH} 6.4,10$ and $21 \mathrm{mg} / \mathrm{kg} \mathrm{P}$ and $\mathrm{K}$, respectively, was the pot medium. Plants were grown in a greenhouse at $18-30 \mathrm{C}$ with $12 \mathrm{~h}$ photoperiod (combined incandescent and cool white fluorescent light) and watered once a day. Fifteenday-old red-fescue and sudangrass seedlings were inoculated with 40-70 spores sandwiched between two layers of roots. Pot cultures were harvested after a year, spores extracted, roots stained (Phillips and Hayman, 1970) and examined for the presence of mycorrhizae. About 50 field- and 50 pot-collected spores were mounted in polyvinyl alcohol/lactic acid/glycerol (PVLG) (Koske and Tessier, 1983) and examined. Another 1020 spores were crushed in a mixture of PVLG and Melzer's reagent $(1: 1, \mathrm{v} / \mathrm{v})$. Wall descriptions and terminology follow those suggested by Morton (1986), Spain et al. (1989), and Walker (1983, 1986). Spore color was examined under a dissecting microscope on freshly collected specimens immersed in water. Colors were determined according to Kornerup and Wanscher (1983). Specimens have been preserved in $5 \%$ formalin and PVLG and deposited in the Department of Plant Pathology (DPP), Academy of Agriculture, Szczecin, Poland, and in the herbarium at Oregon State University (OSC), USA. Spelling of scientific names is according to $\mathrm{Al}$ meida (1989) and Walker (1991). Classification is that of Morton and Benny (1990).

\section{Scutellospora armeniaca Błaszkowski, sp. nov.}

Figs. 1-11

Sporocarpia ignota. Sporae singulae in solo vel in radicibus efformatae, terminaliter vel lateraliter gestae; armeniaco-luteae vel flavido-brunneae; globosae vel subglobosae; (140-)196(-240) $\mu \mathrm{m}$ diam; aliquando ovoideae; $140-200 \times 220-250 \mu \mathrm{m}$. Tunica sporae e stratis septem in turmis duabus. Turma externa e stratis tribus (strati 1-3); uno rigido, griseolo-aurantiaco, (0.7-)0.9(-1.2) $\mu \mathrm{m}$ crasso; duobus laminato, armeniaco-luteo vel flavido-brunneo, (5.4-)8.7(-13) $\mu \mathrm{m}$ crasso, in solutione Melzeri aliquando granato-rubro; tribus 